\title{
Screening of Genes Specifically Expressed in Males of Fenneropenaeus chinensis and Their Potential as Sex Markers
}

\author{
Shihao Li, ${ }_{1}$ Fuhua Li, ${ }^{1}$ Yusu Xie,, ${ }^{1,2}$ Bing Wang, ${ }^{1}$ Rong Wen, ${ }^{1,2}$ Chengsong Zhang, \\ Kuijie Yu, ${ }^{1}$ and Jianhai Xiang ${ }^{1}$ \\ ${ }^{1}$ Key Laboratory of Experimental Marine Biology, Institute of Oceanology, Chinese Academy of Sciences, 7 Nanhai Road, \\ Qingdao 266071, China \\ ${ }^{2}$ Graduate University of Chinese Academy of Sciences, Beijing 100049, China
}

Correspondence should be addressed to Fuhua Li; fhli@qdio.ac.cn

Received 10 May 2013; Revised 22 July 2013; Accepted 30 July 2013

Academic Editor: Katsutoshi Arai

Copyright (C) 2013 Shihao Li et al. This is an open access article distributed under the Creative Commons Attribution License, which permits unrestricted use, distribution, and reproduction in any medium, provided the original work is properly cited.

\begin{abstract}
The androgenic gland (AG), playing an important role in sex differentiation of male crustacean, is a target candidate to understand the mechanism of male development and to mine male-specific sex markers. An SSH library (designated as male reproductionrelated tissues-SSH library, MRT-SSH library for short) was constructed using cDNA from tissues located at the basal part of the 5th pereiopods, including AG and part of spermatophore sac, as tester, and the cDNA from the basal part of the 4th pereiopods of these male shrimp as driver. 402 ESTs from the SSH library were sequenced and assembled into 48 contigs and 104 singlets. Twelve contigs and 14 singlets were identified as known genes. The proteins encoded by the identified genes were categorized, according to their proposed functions, into neuropeptide hormone and hormone transporter, RNA posttranscriptional regulation, translation, cell growth and death, metabolism, genetic information processing, signal transduction/transport, or immunity-related proteins. Eleven highly expressed contigs in the SSH library were selected for validation of the MRT-SSH library and screening sex markers of shrimp. One contig, specifically expressed in male shrimp, had a potential to be developed as a transcriptomic sex marker in shrimp.
\end{abstract}

\section{Introduction}

The existence of sex dimorphism is a very common phenomenon in crustaceans. A number of crustacean species exhibit bimodal growth patterns in which males exhibit superior growth to females or vice versa [1]. Female penaeid shrimps usually show superior growth than males when they reach maturation. For example, females exhibit approximately $10-20 \%$ higher growth rate than males in Penaeus monodon [2]. Therefore, culture of monosex population is a good way to raise the production of cultured species.

Understanding the mechanism of sex determination and sex differentiation will facilitate the development of molecular tools for producing monosex populations in crustacean species [3]. However, little information about sex determination cascades and sexdiagnostic markers is available in penaeid shrimp [4]. A ZW sex determination system in penaeid shrimp was proposed based on the data that the progeny of interspecific hybridization between females of P. monodon and males of Penaeus esculentus had a higher proportion (86\%) of males than females [5]. The following reports that female specific-markers were found in the female genetic linkage maps for Penaeus japonicus [6] and Litopenaeus vannamei [7] and that the induced triploids P. japonicus were always female $[8,9]$ also support the previous hypothesis that a ZW sex determination mechanism might exist in penaeid shrimp. However, in the induced triploid population of $F$. chinensis, although more female triploid shrimp were obtained, males still existed in the triploid population [10]. The existence of male offspring in the triploid Chinese shrimp might be caused by the polar body I induction, which also brought male triploid offspring in Marsupenaeus japonicus [11]. This phenomenon made the sex determination system of penaeid shrimp more complicated than simple $\mathrm{X} / \mathrm{Y}$ or $\mathrm{Z} / \mathrm{W}$ 
systems. A recent report showed that no apparent sex bivalent was observed in male $F$. chinensis through synaptonemal complex (SC) analysis, which suggested that the male shrimp might be the homogametic sex [12]. Our previous studies have demonstrated that the sex determination of penaeid shrimp might adopt a similar mechanism with that in Drosophila [13]. However, the current information still limits our understanding on the sex determination mechanism of penaeid shrimp.

Development of sex markers can facilitate the development of monosex production techniques. Attempts have been made to seek sex markers on genomic DNA and RNA levels. Although it failed to isolate sex-related markers from genomic DNA through bulked segregant analysis (BSA) and AFLP method, it worked at the RNA level through RAPPCR between testes and ovaries in P. monodon [4]. A sexrelated cDNA fragment was isolated from $F$. chinensis through DDRT [14]. Sex-related genes expressed in the ovary and testis of $P$. monodon were identified by EST approach $[15,16]$ and suppression subtractive hybridization (SSH) approach in Marsupenaeus japonicus [17]; these genes were regarded as having a potential to be developed into sex markers. At DNA level, sex-linked AFLP marker was reported in the black tiger shrimp P. monodon [18].

Androgenic gland $(\mathrm{AG})$ of crustacean is an endocrine gland unique to males. Since it was firstly identified in Orchestia gammarella by Charniaux-Cotton (1954), more and more evidence showed that AG played a key role in sex differentiation of crustacean [3, 19-24]. In penaeid shrimp, it was reported that destruction of AG at early juvenile stage could affect the development of the secondary sex characteristics of shrimp [25]. Research on sex determination and the achievement of female monosex culture in future shrimp aquaculture will require a method to determine the gender at early juvenile stages. Secondary sexual characteristics of juvenile shrimp are acquired through progressive molting, until development of external sex characteristics [26]. In this case, some markers which are closely related to the development of sex need to be developed in order to detect the sex ratio at early time. Due to the special function of AG in crustacean, it is possible to identify the specifically expressed genes in AG. The discovery of these genes is not only very helpful to understand the molecular mechanism of AG in sex determination of shrimp, but also to develop sex-specific markers at an early development stage.

$\mathrm{SSH}$ is regarded as a very powerful method to discover differentially expressed genes [27]. SSH was successfully used to identify a novel gene of unknown function in the epithelial cells of the male reproductive tract of Macrobrachium rosenbergii [28], Cq-IAG, and MrIAG which were uniquely expressed in the AG of Cherax quadricarinatus and Macrobrachium rosenbergii was also obtained by SSH [29, 30]. In the present study, SSH was used for screening the differentially expressed genes in male reproductive-related tissues, including AG and part of spermatophore, from Chinese shrimp F. chinensis. The expression of the genes with high abundance was detected in different tissues and different sex, and one potential transcriptomic sex marker of F. chinensis was isolated.

\section{Materials and Methods}

2.1. Shrimp and Tissues. Mature F. chinensis males, with a body length of $10.0 \pm 0.5 \mathrm{~cm}$ and weight of $11.1 \pm 0.5 \mathrm{~g}$, were purchased from a local shrimp farm and reared in the aquarium of our institute. The target tissue located at the base of the fifth pereiopods (the approximate location of the AG in male F. chinensis, including AG and part of the spermatophore sac) and the control tissue, the basal of the fourth pereiopods were dissected from 20 male individuals and preserved in liquid nitrogen immediately for SSH library construction.

The tissues including hemocytes, muscle, gill, hepatopancreas, nerve cord, cuticle, eyestalk, ovary, testis, vas deferens, and the combined tissues of AG with part of spermatophore sac (AG was distributed scattered and hardly isolated in the Chinese shrimp) were sampled from five females or five males adult individuals and preserved in liquid nitrogen separately for verification of ESTs from the constructed MRTSSH library.

The cephalothoraxes of five females or five males at growup stage (body length: $7.1 \pm 0.3 \mathrm{~cm}$ and body weight: $5.1 \pm$ $0.6 \mathrm{~g}$ ) were sampled separately for primarily screening of sex markers.

Nineteen female juvenile Chinese shrimps (body length: $6.0 \pm 0.5 \mathrm{~cm}$ and body weight: $3.0 \pm 0.2 \mathrm{~g}$ ) and 20 male juvenile Chinese shrimps (body length: $6.4 \pm 0.5 \mathrm{~cm}$ and body weight: $3.7 \pm 0.2 \mathrm{~g}$ ) at stage PL75 (75 days after metamorphosis to postlarvae, when the external sex phenotype began to appear) were collected and their cephalothoraxes were dissected and preserved in liquid nitrogen individually for RNA extraction in order to be used for sex markers' screening.

Shrimps from different postlarvae (PL) stages, including PL15, PL30, PL45, PL60, PL75, PL90, and PL105, were also sampled for transcriptional detection of potent sex markers in different developmental stages.

2.2. Construction of the SSH Library. Total RNA was extracted from AG-containing target tissue (tester) and the control tissue (driver) using Unizol Reagent (BioStar, China) following the manufacturer's protocol. RNA quality was assessed by electrophoresis on 1.2\% agarose gel. mRNA was then purified from total RNA with mRNA purification Kit (QIAGEN, Germany). Suppression subtractive hybridization (SSH) was performed with the PCR-Select cDNA Subtraction Kit (Clontech, USA). Briefly, tester double-strand cDNA and driver double-strand cDNA were synthesized from $2 \mu \mathrm{g}$ each of the two mRNA samples and then digested with Rsa I. The digested tester cDNA was separated into two aliquots and then ligated to two different cDNA adaptors, respectively. During a first hybridization, excess driver was added to tester cDNA samples, which were then denatured and allowed to anneal. In the second hybridization, the two primary hybridization samples were mixed without denaturation. To further screen differentially expressed sequences, denatured driver cDNA was again added to these hybrid samples. As a result, the remaining subtracted equalized single-stranded tested cDNA reassociated to form hybrids with a different adaptor on each end. This subtracted sample was then used 
TABLE 1: List of primers with their information used for RT-PCR.

\begin{tabular}{|c|c|c|c|c|}
\hline Gene symbol & Gene common name & Primers $5^{\prime}-3^{\prime}$ & $T\left({ }^{\circ} \mathrm{C}\right)$ & Product size (bp) \\
\hline \multirow{2}{*}{ Contig10 } & \multirow{2}{*}{ Unknown } & F-AAGTGGTGCTAGTCGTTGC & \multirow{2}{*}{54} & \multirow{2}{*}{336} \\
\hline & & R-GGAGGGTCCTGCTTCTGT & & \\
\hline \multirow{2}{*}{ Contig14 } & \multirow{2}{*}{ Unknown } & F-TGTGGACCTGCCTTCTT & \multirow{2}{*}{55} & \multirow{2}{*}{342} \\
\hline & & R-CGTATTTAGTGGCTGAGTG & & \\
\hline \multirow{2}{*}{ Contig16 } & \multirow{2}{*}{ Unknown } & F-GTGCTGGCGTCAGAGGGTAT & \multirow{2}{*}{60} & \multirow{2}{*}{539} \\
\hline & & R-TTGGTTAGATCGGTGAGGAGTC & & \\
\hline \multirow{2}{*}{ Contig19 } & \multirow{2}{*}{ Unknown } & F-GTGAAACTGTGAGACTTATCCCTGT & \multirow{2}{*}{60} & \multirow{2}{*}{152} \\
\hline & & R-GCAACTACGAGATGAAGAATCCAAT & & \\
\hline \multirow{2}{*}{ Contig26 } & \multirow{2}{*}{ Unknown } & F-AGAAGCGAGAATCATAAGAGG & \multirow{2}{*}{53} & \multirow{2}{*}{213} \\
\hline & & R-TACGGCAGTTGTCCAGAA & & \\
\hline \multirow{2}{*}{ Contig31 } & \multirow{2}{*}{ Unknown } & F-CGTCCAGGTTTCATCGC & \multirow{2}{*}{55} & \multirow{2}{*}{408} \\
\hline & & R-CACGGAGGCATCCATCT & & \\
\hline \multirow{2}{*}{ Contig32 } & \multirow{2}{*}{ Unknown } & F-GAGGTTCTGATAAAGTCGTGGGT & \multirow{2}{*}{60} & \multirow{2}{*}{119} \\
\hline & & R-GTATGCGTTGATTCTCGTAGCG & & \\
\hline \multirow{2}{*}{ Contig39 } & \multirow{2}{*}{ Unknown } & F-ATGCTCCTCTTTGCTCTTCCGT & \multirow{2}{*}{62} & \multirow{2}{*}{327} \\
\hline & & R-TGTTATCTGTGTCGCCTTTGCC & & \\
\hline \multirow{2}{*}{ Contig47 } & \multirow{2}{*}{ Unknown } & F-GAACCTGCTGAGGAACTTGAATGT & 62 & 158 \\
\hline & & R-TCCCCAACCAGTTCAGCCTAC & & \\
\hline Contio48 & Unknown & F-GAGGTTCTGATAAAGTCGTGG & 54 & 138 \\
\hline Conitigto & Cกลก & R-GTCTGTTGCTGGCGATG & 87 & 100 \\
\hline $\mathrm{CHH}$ & Crustacean hyperglycemic hormone & F-GTTTTGTCCTCAAGCCTCTCTC & 57 & 289 \\
\hline & & R-GCGGAGTGGGACTACTTACC & & \\
\hline 18S-rRNA & 18S-rRNA & F-TCTGCCCTATCAACTTTCGATGGTA & 64 & 257 \\
\hline 180-IKINA & IOS-IKINA & R-AATTTGCGCGCCTGCTGCCTTCCTT & 04 & 231 \\
\hline
\end{tabular}

F: forward; R: reverse; $T$ : annealing temperature.

in PCR to amplify the differentially expressed sequences. The final PCR product was purified using the QIAGEN PCR Purification Kit, inserted into pGEM-T Easy vector (Promega, USA), then transformed into E. coli $\mathrm{DH} 5 \alpha$ cells, plated onto LB medium containing ampicillin, X-gal, and IPTG, and then cultured overnight. White clones were selected randomly and amplified by PCR using Nested PCR primer 1 and 2R from PCR-Select cDNA Subtraction Kit. Agarose gel electrophoresis was performed to visualize the amplified fragments and to select the samples for sequencing from forward subtraction library (those from reverse subtraction library were not detected and sequenced). The previously mentioned PCR programs and control subtraction were all performed according to the manufacture's protocols.

2.3. Bioinformatic Analysis. The obtained cDNA sequences were first stripped of the vector and primer sequences using the online program BLAST. Clustering and assembly of the sequences were performed using ContigExpress (Informax 2003 software) with the following parameters: overlap: 20; identity: 0.85; cut-off score: 40 . The resulting contigs and singlets were unified and their sequences were compared to the GenBank database using BLASTx analysis from NCBI. The sequences that had no hit in the GenBank database were carried out with Swiss-prot analysis.
2.4. Reverse Transcription-Polymerase Chain Reaction (RTPCR). Eleven contigs (contig10, 14, 16, 19, 26, 31, 32, 39, 47, 48, and $\mathrm{CHH}$ ) from the MRT-SSH library were selected to be verified by RT-PCR. Total RNA, extracted from AGcontaining target tissue, the control tissue, haemocytes, muscle, gill, hepatopancreas, nerve cord, cuticle, eyestalk, ovary, testis, vas deferens, and the combined tissues of AG with part of spermatophore sac, was treated with RQ1 RNase-Free DNase (Promega, USA) to remove contaminated DNA from the total RNA. cDNA was synthesized from $2 \mu \mathrm{g}$ total RNA by M-MLV reverse transcriptase (Promega, USA) following the manufacturer's protocol with random hexamer primer $\left(5^{\prime}\right.$-NNN NNN-3'). The primer's sequences of 11 selected specific transcripts and 18S-rRNA were shown in Table 1. PCR reactions were performed with a denaturation step of $94^{\circ} \mathrm{C}$ for $4 \mathrm{~min}$ followed by 26 cycles of $94^{\circ} \mathrm{C}$ for $30 \mathrm{~s}, 50^{\circ} \mathrm{C}-64^{\circ} \mathrm{C}$ for $30 \mathrm{~s}$, and $72^{\circ} \mathrm{C}$ for $30 \mathrm{~s}$ and then kept for $10 \mathrm{~min}$ at $72^{\circ} \mathrm{C}$ for the final extension. PCR products were analyzed on $2 \%$ agarose gel, stained with ethidium bromide, and visualized under ultraviolet light.

2.5. Screening of Sex Markers in Chinese Shrimp. Total RNA extraction and cDNA synthesis for the cephalothoraxes of female or male grow-up stage shrimp and each juvenile shrimp were performed as described previously. 


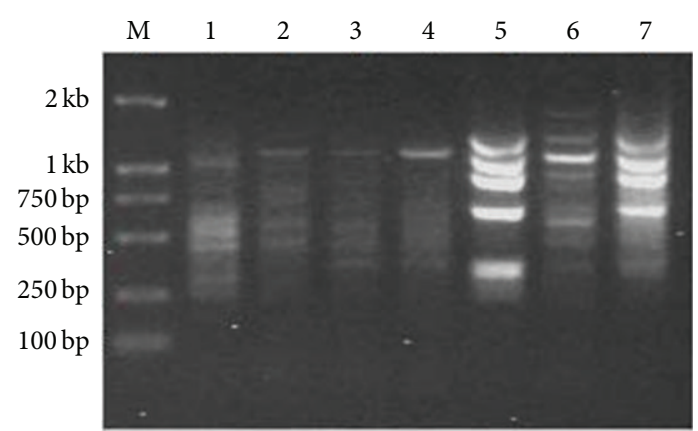

FIGURE 1: Detection of the secondary PCR products of (1) forwardsubtracted experimental cDNA which was highly expressed in MRT; (2) unsubtracted total cDNA from MRT; (3) reverse-subtracted experimental cDNA which was highly expressed in the shrimp control tissue; (4) unsubtracted total cDNA from the shrimp control tissue; (5) subtracted control skeletal muscle cDNA from SSH kit; and (6) unsubtracted tester control for the control subtraction from SSH kit; and (7) PCR control-subtracted cDNA from SHH kit.

Eleven selected genes were detected using RT-PCR in the cephalothoraxes of female and male shrimp for primarily screening of sex markers and detected in each juvenile for further screening of sex markers, respectively.

\section{Results}

3.1. Suppression Subtractive Hybridization. To testify the subtraction efficiency, control subtraction was carried out with human skeletal muscle tester (containing 0.2\% HaeIII digested $\varphi$ X174) and driver cDNAs, in parallel with the experimental forward and reverse subtraction according to the protocol of the kit. After the secondary PCR, correct $\varphi \mathrm{X} 174 / \mathrm{Ha} I I I$ bands appeared in both control subtraction (Figure 1, lane 5) and the positive PCR control (Figure 1, lane 7; which was provided by the kit, containing a successfully subtracted mixture of HaeIIIdigested $\varphi$ X174 DNA). The experimental secondary PCR subtraction products (Figure 1, lanes 1 and 3) appeared as a smear from $0.2-2 \mathrm{~kb}$. After purification, the forward subtracted PCR products were used to generate forward subtracted libraries, with the titers of $3 \times 10^{5} \mathrm{pfu} / \mathrm{mL}$. The recombination rate was more than $97 \%$ with the majority of inserted cDNA fragments from $250 \mathrm{bp}$ to $1000 \mathrm{bp}$.

3.2. Highly Expressed Genes in the AG-Related Tissues of Chinese Shrimp. In the MRT-SSH library, 432 clones were sequenced and 402 ESTs were obtained. They were further assembled into 152 nonredundant gene clusters, including 48 contigs and 104 singlets. As shown in Figure 1, the majority $(82.6 \%)$ of the obtained ESTs shared no significant similarity $\left(E>1 \times 10^{-4}\right)$ to any of the known genes and proteins in NCBI database; $2.0 \%$ of those ESTs shared significant similarity to the genes encoding hypothetical proteins without any annotation; the remaining sequences encoded 23 putative genes shown in Table 2.

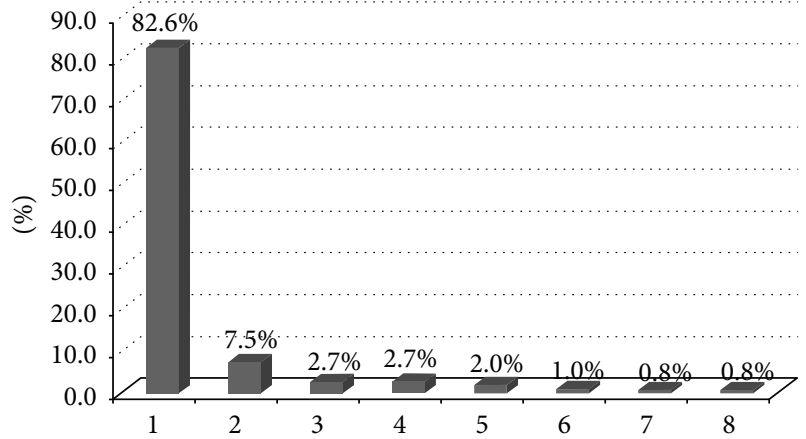

FIgURE 2: Percentages (\%) of ESTs related to gene function in the MRT-SSH library. (1) Unknown genes; (2) neuropeptide hormone/hormone transporter; (3) ribosome protein; (4) RNA binding protein; (5) hypothetical protein; (6) related to development/communication; (7) immune related; (8) enzyme.

Out of the 402 ESTs in the MRT-SSH library constructed in this study, genes related to neuropeptide hormone and hormone transporter account for $7.5 \%$ (30/402), which took a greater proportion than those related to ribosome protein $2.7 \%$ (11/402), RNA-binding protein $(2.7 \%$, $11 / 402)$, development and communication (1.0\%, 4/402), immune $(0.8 \%, 3 / 402)$, and enzyme $(0.8 \%, 3 / 402)$ (Figure 2$)$. The swissprot analysis result for the unknown sequences was shown in Supplementary Table 1 available online at http://dx.doi.org/10.1155/2013/921067.

3.3. Validation of Selected Differentially Expressed Genes. Eleven transcripts with a high percentage in the MRTSSH library (Table 3) were selected for tissue distribution verification. As shown in Table 3, ESTs of contig10, 14, 16, $19,26,31,32,39,47,48$, and $\mathrm{CHH}$ accounted for $6.02 \%$, $0.46 \%, 3.94 \%, 2.78 \%, 3.70 \%, 6.71 \%, 2.55 \%, 2.31 \%, 2.78 \%$, $0.93 \%$, and $5.09 \%$ in the total 402 ESTs, respectively. They were confirmed by RT-PCR in the AG-related tissues, control tissue, and other tissues. All the selected genes were only detected in the combined tissues of AG with part of the spermatophore sac except contig16, which was also detected in testis (Table 4).

3.4. A Potential Transcriptomic Sex Marker Was Selected by $R T-P C R$. As the selected 11 candidates were verified to be expressed either in AG-related tissues or in testis, both of which were located in the cephalothoraxes of shrimps, the cephalothoraxes of female and male grow-up stage shrimps were sampled to identify the genes expression in different sexes. All of them were only detected in male shrimps (Figure 3).

For further screening of sex markers in the Chinese shrimp, the selected genes were confirmed in 39 individuals at early juvenile stage (PL75), including 19 female shrimps and 20 male ones, by RT-PCR. Data showed that only contig16 (GenBank number KC354368) was confirmed to be expressed at the early juvenile stage PL75 in the shrimp and exclusively expressed in male ones (Figure 4). 
TABLE 2: Blast homology search results of genes isolated from the MRT-SSH library.

\begin{tabular}{|c|c|c|c|c|c|}
\hline Cluster & No. of clones & Highest BLASTX match & Accession number & Species & $E$ value \\
\hline \multirow{3}{*}{$\begin{array}{l}\text { Neuropeptide hormone } \\
\text { and hormone transporter }\end{array}$} & 7 & $\begin{array}{l}\text { Ion-transport peptide } \\
\text { precursor-like protein transcript } 1\end{array}$ & AAY29662 & Aedes aegypti & $1 E-05$ \\
\hline & 22 & $\begin{array}{l}\text { Hyperglycemic hormone-like } \\
\text { neuropeptide } 43-2\end{array}$ & AAD45234 & Metapenaeus ensis & $2 \mathrm{E}-09$ \\
\hline & 1 & $\begin{array}{l}\text { Sodium-neurotransmitter } \\
\text { symporter, putative }\end{array}$ & EEC18529 & Ixodes scapularis & $8 E-61$ \\
\hline \multirow{5}{*}{ RNA binding protein } & 3 & RD RNA-binding protein & XP_002714359 & Oryctolagus cuniculus & $8 E-06$ \\
\hline & 4 & CRX like homeobox 2 & ABC69291 & Homo sapiens & $7 E-08$ \\
\hline & 1 & $\begin{array}{l}\text { Negative elongation factor E-like } \\
\text { protein }\end{array}$ & ABQ22564 & Callithrix jacchus & $2 E-06$ \\
\hline & 1 & RNA binding motif protein 25 & XP_001916318 & Equus caballus & $3 E-04$ \\
\hline & 1 & RBM 25 protein & XP_001520202 & Ornithorhynchus anatinus & $5 E-07$ \\
\hline \multirow{3}{*}{$\begin{array}{l}\text { Development- and } \\
\text { communication-related } \\
\text { protein }\end{array}$} & 2 & $\begin{array}{l}\text { Putative senescence-associated } \\
\text { protein }\end{array}$ & BAB33414 & Pisum sativum & $3 E-28$ \\
\hline & 1 & Tetraspanins-like protein- 8 & ABM92445.1 & Fenneropenaeus chinensis & $1 E-99$ \\
\hline & 1 & Programmed cell death $4 \mathrm{a}$ & AAH54680 & Danio rerio & $7 E-17$ \\
\hline \multirow{8}{*}{ Ribosome protein } & 2 & 40 S ribosomal protein S23 & ABI52808 & Argas monolakensis & $1 E-50$ \\
\hline & 2 & Ribosomal protein L26 & ABP 68820 & Penaeus monodon & $6 E-22$ \\
\hline & 2 & Ribosomal protein L24 & AAS45465 & Marsupenaeus japonicus & $7 E-11$ \\
\hline & 1 & Putative ribosomal protein L11 & ABM55572 & Maconellicoccus hirsutus & $1 E-33$ \\
\hline & 1 & Ribosomal protein 113a & AAX62469 & Lysiphlebus testaceipes & $5 E-23$ \\
\hline & 1 & Ribosomal protein S4 & AAV34860 & Bombyx mori & $8 E-55$ \\
\hline & 1 & Ribosomal protein L28 & NP_001037237 & Bombyx mori & $2 E-24$ \\
\hline & 1 & Ribosomal protein S5 isoform A & AAX62467 & Lysiphlebus testaceipes & $1 E-79$ \\
\hline \multirow{2}{*}{ Enzyme } & 1 & Protease $\mathrm{ml}$ zinc metalloprotease & EAT40060 & Aedes aegypti & $9 E-36$ \\
\hline & 1 & Oligosaccharyl transferase & EAT45977 & Aedes aegypti & $2 E-23$ \\
\hline \multirow{2}{*}{ Immune-related protein } & 2 & Antimicrobial peptide & AAX63831 & Fenneropenaeus chinensis & $2 E-22$ \\
\hline & 1 & Antilipopolysaccharide factor & AAY33769 & Litopenaeus stylirostris & $3 E-21$ \\
\hline
\end{tabular}

The specific expression patterns for the identified genes in bold letters was confirmed in another Study (Li et al., 2010 [31]).

TABLE 3: Clones percentage of the selected contigs or gene clusters in the SSH library.

\begin{tabular}{lcc}
\hline Gene symbol & Clones number & Clones percentage (\%) \\
\hline contig10 & 26 & 6.02 \\
contig14 & 2 & 0.46 \\
contig16 & 17 & 3.94 \\
contig19 & 12 & 2.78 \\
contig26 & 16 & 3.7 \\
contig31 & 29 & 6.71 \\
contig32 & 11 & 2.55 \\
contig39 & 10 & 2.31 \\
contig47 & 12 & 2.78 \\
contig48 & 4 & 0.93 \\
CHH & 22 & 5.09 \\
\hline
\end{tabular}

To testify the availability of contig16 as a sex marker in the Chinese shrimp, the transcripts of contig16 were detected in different postlarvae stages, including PL15, PL30, PL45, PL60, PL75, PL90, and PL105. Data revealed that contig16 presented much earlier than PL75. Contig16 was firstly detected at a low expression level in the shrimp at PL45 (Figure 5).

\section{Discussion}

Suppression subtractive hybridization ( $\mathrm{SSH}$ ), which is regarded as an efficient method to isolate differentially expressed genes, is used to study the specifically expressed genes from AG-related tissues. In the sequenced 402 ESTs from the present SSH library, clones encoding neuropeptide hormone and hormone transporter accounted for the biggest part $(7.46 \%, 30 / 402)$ in the total clone number. A fragment, with an annotation of hyperglycemic hormonelike neuropeptide 43-2 of Metapenaeus ensis (Table 2), aroused our interests. Crustacean hyperglycemic hormones (CHHs) are mainly detected in the X-organ sinus gland complex, which is situated in the eyestalks of crustacean [32] and considered to be playing important roles in multiple physiological effects, such as carbohydrate metabolism [33], reproduction [34], osmoregulation [35], and ecdysis [36]. Further study showed that the $\mathrm{CHH}$ gene homologue in 

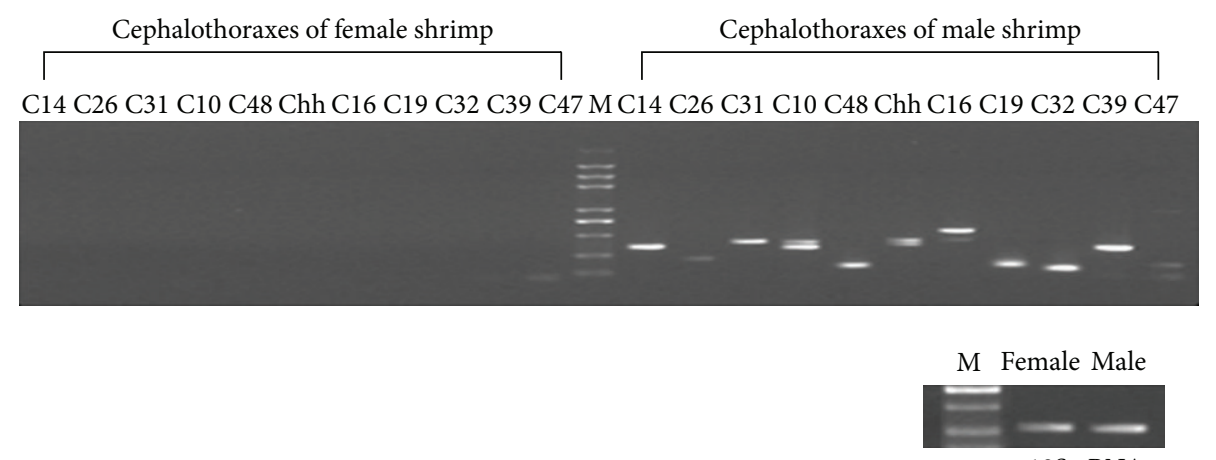

18S-rRNA

FiguRE 3: Expression profile of the selected genes in the cephalothoraxes of female and male shrimps F. chinensis. C (14): contig; M: marker (DL2000); 18S-rRNA was used to normalize the amount of cDNA of female and male shrimps' cephalothoraxes.

TABLE 4: Tissue distribution of selected genes from AG-SSH library of $F$. chinensis.

\begin{tabular}{|c|c|c|c|c|c|c|c|c|c|c|c|}
\hline Gene symbol & $\mathrm{Hc}$ & Mc & $\mathrm{Gi}$ & $\mathrm{Hp}$ & $\mathrm{Nc}$ & $\mathrm{Cu}$ & Es & $\mathrm{Ov}$ & $\mathrm{Te}$ & $\mathrm{AG} \& \mathrm{Sm}$ & 1 \\
\hline contig10 & - & - & - & - & - & - & - & - & - & + & \\
\hline contig14 & - & - & - & - & - & - & - & - & - & + & - \\
\hline cont & - & - & - & - & - & - & - & - & + & + & 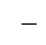 \\
\hline conti & - & - & - & - & - & - & - & - & - & + & 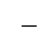 \\
\hline cont & - & - & - & - & - & - & - & - & - & + & - \\
\hline conti & - & - & - & - & - & - & - & - & - & + & - \\
\hline contig32 & - & - & - & - & - & - & - & - & - & + & 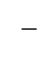 \\
\hline contig39 & - & - & - & - & - & - & - & - & - & + & 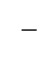 \\
\hline contig 47 & - & - & - & - & - & - & - & - & - & + & 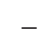 \\
\hline contig 48 & - & - & - & - & - & - & - & - & - & + & 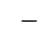 \\
\hline $\mathrm{CHH}$ & - & - & - & - & - & - & - & - & - & + & \\
\hline
\end{tabular}

-: not detected; +: detected; Hc: hemocytes; Mc: muscle; Gi: gill; Hp: hepatopancreas; Nc: nerve cord; Cu: cuticle; Es: eyestalk; Ov: ovary; Te: testis; AG \& Sm: androgenic gland with part of spermatophore sac; C: control tissue.

the MRT-SSH library was exclusively detected at the epithelial cells in the internal wall of the spermatophore sac, which indicated that the $\mathrm{CHH}$ homologue might play roles in the male development of the shrimp F. chinensis [31].

Genes related to the ribosome proteins and RNA-binding proteins highly expressed in the SSH library constructed in this study. As we know, ribosome proteins are the proteins of the ribosomal subunits which are involved in the cellular process of translation. They were generally considered to function in the regulation and activity of the ribosome in cells $[37,38]$. Ribosome proteins were also found to have functions in controlling cell growth and proliferation [39]. A recent study revealed that a ribosome protein L24 was significantly highly expressed in ovary than in other tissues and was considered to play an important role in oogenesis in the marine shrimp M. japonicus [38]. RNA-binding proteins play important roles in posttranscriptional control of RNAs, which is regarded as a vital way to regulate gene expression during development [40]. An RNA-binding protein, RBM25, was confirmed to play roles during programmed cell death via

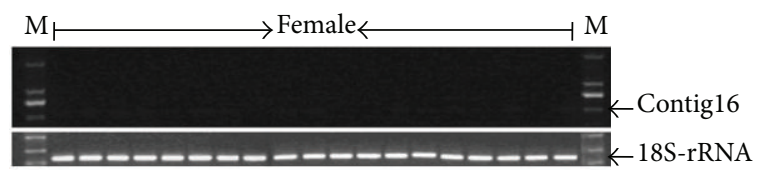

(a)

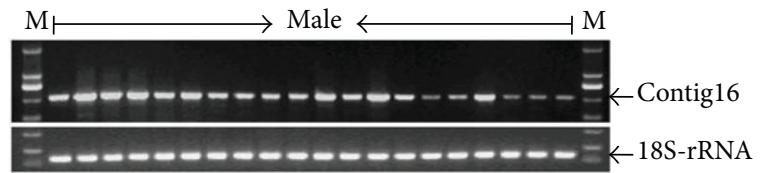

(b)

FIGURE 4: Expression profile of contig16 in the juvenile shrimps of female (a) and male (b) F. chinensis. M: marker (DL2000); 18S-rRNA was used to normalize the amount of cDNA of juvenile female and male shrimps.

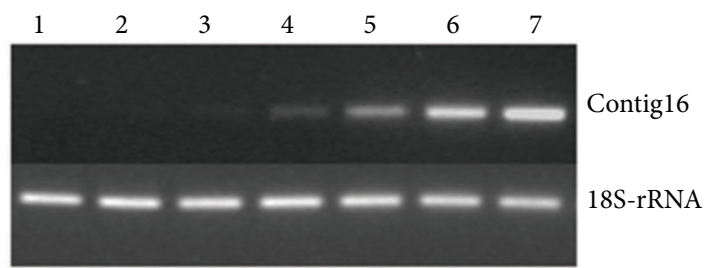

Figure 5: RT-PCR detection of Contig16 in different development stages of $F$. chinensis. Shrimps from different postlarvae (PL) stages were used for transcripts detection. 1-7 represented PL15, PL 30, PL45, PL60, PL75, PL90, and PL105, respectively. 18S-rRNA was used to normalize the amount of cDNA.

interaction with mRNAs of $b c l-x$ [41]. Insulin-like androgenic gland hormone, IAG, plays a key role during male sex differentiation and spermatogenesis in crustacean $[29,30]$. However, beyond our expectation, the IAG gene was not found in the MRT-SSH library. The reason might be that the IAG transcripts are expressed at a low level in the AG. In addition, the tester tissue used in the MRT-SSH library contained not only the AG, but also a big part of spermatophore, which might also lead to the absent of IAG in the limited sequencing ESTs. 
In the constructed MRT-SSH library, as many as $82.89 \%$ of the obtained ESTs shared no significant similarity $(E>$ $1 \times 10^{-4}$ ) to any known genes and proteins in NCBI database, which took a significantly greater proportion when compared to the SSH library between testes of broodstock and juvenile shrimp of P. monodon (62.9\% for forward library and $46.5 \%$ for reverse library) [42] and the SSH library between triploid and diploid shrimp of $F$. chinensis (39\% for forward library and $35 \%$ for reverse library) [43]. Several cDNA libraries have also been constructed to isolate gonad-related genes in shrimps. In P. monodon, there were only $29.3 \%$ unidentified transcripts in the ovary cDNA library [15]. There was also a low proportion $(32.4 \%)$ of unknown transcripts in the cDNA library of testes in $P$. monodon [16]. The high proportion of unknown genes in the MRT-SSH library indicated that there were plenty of new genes to be investigated in the AG and the spermatophore sac. More efforts should be made on the unknown genes in the MRT-SSH library as they occupied the greatest part of the assembled gene clusters of the library and some of them might play important roles in the male developmental activities. In order to learn more about the unknown genes expressed in MRT-SSH library, especially those genes with high expression frequency, 11 transcripts were selected to detect their expression patterns in different tissues or different sex individuals. Gonad-specific transcripts were already obtained from the SSH library in $M$. japonicus [17]. Above selected transcripts were all male-specific which inspired our interests to screen sex markers in the shrimp $F$. chinensis.

After a two-step screening of the selected gene clusters, the contig16, without annotation in the NCBI database, was finally verified to be specifically expressed in males at the juvenile stage PL75, when the external phenotypic sex characteristics of the shrimp began to be recognized. Histological studies revealed that the internal sex characteristics were detected much earlier than the external sex phenotype in penaeid shrimp $[44,45]$. So the contig16 probably expressed at an earlier stage when the internal sex characteristics were developed. Detection of contig16 in developmental stages revealed that it could also be detected in PL45. This implied that contig16 had a potential to be developed as a transcriptomic sex marker in the shrimp F. chinensis to test the approximate gender ratio of the cultured shrimp at an early developmental stage.

The monosex culture of crustacean was tried and succeeded in Macrobrachium rosenbergii [3, 46]. However, no great progress was made in sex control of penaeid shrimp. The isolation of sex markers, which could be used to identify male shrimps from female ones during polyploidy breeding and aquaculture, would encourage us to speed up the establishment of monosex population culture.

In summary, an SSH library of the male reproductiverelated tissues of the shrimp F. chinensis was successfully constructed. Most of the sequenced ESTs were assembled to be unknown genes and some of them were selected to verify the efficiency of the SSH library and to screen sex markers in the shrimp F. chinensis. A potential transcriptomic sex marker was isolated and could be used to detect the gender of Chinese shrimp at the early juvenile developmental stage. But more investigations should be taken to analyze the SSH library, especially on the biological function and characterization of the unknown genes. This is the basis to understand the molecular mechanism of male reproduction in order to develop sex control strategy in shrimp culture.

\section{Acknowledgments}

This work was financially supported by General Program of National Natural Science Foundation of China (30871909, 40676087, and 31072203) and Key Program of National Natural Science Foundation of China 30730071.

\section{References}

[1] R. G. Hartnoll, “Growth,” in The Biology of Crustacea, D. E. Bliss, Ed., pp. 111-197, 1982.

[2] C. L. Browdy, "Recent developments in penaeid broodstock and seed production technologies: improving the outlook for superior captive stocks," Aquaculture, vol. 164, no. 1-4, pp. 3-21, 1998.

[3] A. Sagi and E. D. Aflalo, "The androgenic gland and monosex culture of freshwater prawn Macrobrachium rosenbergii (De Man): a biotechnological perspective," Aquaculture Research, vol. 36, no. 3, pp. 231-237, 2005.

[4] B. Khamnamtong, S. Thumrungtanakit, S. Klinbunga, T. Aoki, I. Hirono, and P. Menasveta, "Identification of sex-specific expression markers in the giant tiger shrimp (Penaeus monodon)," Journal of Biochemistry and Molecular Biology, vol. 39, no. 1, pp. 37-45, 2006.

[5] J. A. H. Benzie, M. Kenway, and E. Ballment, "Growth of Penaeus monodon $\times$ Penaeus esculentus tiger prawn hybrids relative to the parental species," Aquaculture, vol. 193, no. 3-4, pp. 227-237, 2001.

[6] Y. T. Li, K. Byrne, E. Miggiano et al., "Genetic mapping of the kuruma prawn Penaeus japonicus using AFLP markers," Aquaculture, vol. 219, no. 1-4, pp. 143-156, 2003.

[7] L. S. Zhang, C. J. Yang, Y. Zhang et al., "A genetic linkage map of Pacific white shrimp (Litopenaeus vannamei): sex-linked microsatellite markers and high recombination rates," Genetica, vol. 131, no. 1, pp. 37-49, 2007.

[8] M. Sellars, F. Coman, B. Norris, and N. Preston, "Relative survival and growth rates of triploid and diploid female Penaeus japonicus," in World Aquaculture Society Book of Abstracts, p. 713, 2003.

[9] M. Sellars, F. Coman, and N. Preston, "Protecting genetically improved shrimp via induced sterility," in Australasian Aquaculture Book of Abstracts, p. 265, 2004.

[10] F. H. Li, J. H. Xiang, X. J. Zhang, L. H. Zhou, C. S. Zhang, and C. G. Wu, "Gonad development characteristics and sex ratio in triploid Chinese shrimp (Fenneropenaeus chinensis)," Marine Biotechnology, vol. 5, no. 6, pp. 528-535, 2003.

[11] M. J. Sellars, A. T. Wood, T. J. Dixon, L. M. Dierens, and G. J. Coman, "A comparison of heterozygosity, sex ratio and production traits in two classes of triploid Penaeus (Marsupenaeus) japonicus (Kuruma shrimp): polar body I versus II triploids," Aquaculture, vol. 296, no. 3-4, pp. 207-212, 2009.

[12] Y. S. Xie, F. H. Li, C. S. Zhang, K. J. Yu, and J. H. Xiang, "Synaptonemal complex analysis in spermatocytes of diploid 
and triploid Chinese shrimp Fenneropenaeus chinensis," Tissue and Cell, vol. 40, no. 5, pp. 343-350, 2008.

[13] S. H. Li, F. H. Li, R. Wen, and J. H. Xiang, "Identification and characterization of the sex-determiner transformer-2 homologue in Chinese shrimp, Fenneropenaeus chinensis," Sexual Development, vol. 6, pp. 267-278, 2012.

[14] B. Wang, Y. J. Fan, X. J. Zhang, F. H. Li, and J. H. Xiang, "The preliminary study on the sexual related dna fragment in Chinese shrimp," High Technology Letters, vol. 13, pp. 82-86, 2003.

[15] R. Preechaphol, R. Leelatanawit, K. Sittikankeaw et al., "Expressed sequence tag analysis for identification and characterization of sex-related genes in the giant tiger shrimp Penaeus monodon," Journal of Biochemistry and Molecular Biology, vol. 40, no. 4, pp. 501-510, 2007.

[16] R. Leelatanawit, K. Sittikankeaw, P. Yocawibun et al., "Identification, characterization and expression of sex-related genes in testes of the giant tiger shrimp Penaeus monodon," Comparative Biochemistry and Physiology A, vol. 152, no. 1, pp. 66-76, 2009.

[17] T. R. Callaghan, B. M. Degnan, and M. J. Sellars, "Expression of sex and reproduction-related genes in Marsupenaeus japonicus," Marine Biotechnology, vol. 12, no. 6, pp. 664-677, 2010.

[18] J. Staelens, D. Rombaut, I. Vercauteren, B. Argue, J. Benzie, and M. Vuylsteke, "High-density linkage maps and sex-linked markers for the black tiger shrimp (Penaeus monodon)," Genetics, vol. 179, no. 2, pp. 917-925, 2008.

[19] Z. X. Cui, H. Liu, T. S. Lo, and K. H. Chu, "Inhibitory effects of the androgenic gland on ovarian development in the mud crab Scylla paramamosain," Comparative Biochemistry and Physiology A, vol. 140, no. 3, pp. 343-348, 2005.

[20] R. J. Fowler and B. V. Leonard, "The structure and function of the androgenic gland in Cherax destructor (Decapoda: Parastacidae)," Aquaculture, vol. 171, no. 1-2, pp. 135-148, 1999.

[21] A. Sagi and I. Khalaila, "The crustacean androgen: a hormone in an isopod and androgenic activity in decapods"' The American Zoologist, vol. 41, no. 3, pp. 477-484, 2001.

[22] A. Sagi, R. Manor, C. Segall, C. Davis, and I. Khalaila, "On intersexuality in the crayfish Cherax quadricarinatus: an inducible sexual plasticity model," Invertebrate Reproduction and Development, vol. 41, no. 1-3, pp. 27-33, 2002.

[23] A. Sagi, E. Snir, and I. Khalaila, "Sexual differentiation in decapod crustaceans: role of the androgenic gland," Invertebrate Reproduction and Development, vol. 31, no. 1-3, pp. 55-61, 1997.

[24] S. Suzuki, "Androgenic gland hormone is a sex-reversing factor but cannot be a sex-determining factor in the female crustacean isopods Armadillidium vulgare," General and Comparative Endocrinology, vol. 115, no. 3, pp. 370-378, 1999.

[25] F. H. Li and J. H. Xiang, "Preliminary studies on form, structure and function of androgenic gland in Penaeus chinensis," Chinese Science Bulletin, vol. 42, no. 6, pp. 499-503, 1997.

[26] R. Campos-Ramos, R. Garza-Torres, D. A. Guerrero-Tortolero, A. M. Maeda-Martínez, and H. Obregón-Barboza, "Environmental sex determination, external sex differentiation and structure of the androgenic gland in the Pacific white shrimp Litopenaeus vannamei (Boone)," Aquaculture Research, vol. 37, no. 15, pp. 1583-1593, 2006.

[27] L. Diatchenko, S. Lukyanov, Y. F. C. Lau, and P. D. Siebert, "Suppression subtractive hybridization: a versatile method for identifying differentially expressed genes," Methods in Enzymology, vol. 303, pp. 349-380, 1999.
[28] J. X. Cao, G. L. Yin, and W. J. Yang, "Identification of a novel male reproduction-related gene and its regulated expression patterns in the prawn, Macrobrachium rosenbergii," Peptides, vol. 27, no. 4, pp. 728-735, 2006.

[29] R. Manor, S. Weil, S. Oren et al., "Insulin and gender: an insulinlike gene expressed exclusively in the androgenic gland of the male crayfish," General and Comparative Endocrinology, vol. 150, no. 2, pp. 326-336, 2007.

[30] T. Ventura, R. Manor, E. D. Aflalo et al., “Temporal silencing of an androgenic gland-specific insulin-like gene affecting phenotypical gender differences and spermatogenesis," Endocrinology, vol. 150, no. 3, pp. 1278-1286, 2009.

[31] S. H. Li, F. H. Li, B. Wang, Y. S. Xie, R. Wen, and J. H. Xiang, "Cloning and expression profiles of two isoforms of a CHH-like gene specifically expressed in male Chinese shrimp, Fenneropenaeus chinensis," General and Comparative Endocrinology, vol. 167, no. 2, pp. 308-316, 2010.

[32] R. Keller, "Crustacean neuropeptides: structures, functions and comparative aspects," Experientia, vol. 48, no. 5, pp. 439-448, 1992.

[33] M. L. Fanjul-Moles, "Biochemical and functional aspects of crustacean hyperglycemic hormone in decapod crustaceans: review and update," Comparative Biochemistry and Physiology C, vol. 142, no. 3-4, pp. 390-400, 2006.

[34] D. P. V. de Kleijn and F. van Herp, "Involvement of the hyperglycemic neurohormone family in the control of reproduction in decapod crustaceans," Invertebrate Reproduction and Development, vol. 33, no. 2-3, pp. 263-272, 1998.

[35] L. Serrano, G. Blanvillain, D. Soyez et al., "Putative involvement of crustacean hyperglycemic hormone isoforms in the neuroendocrine mediation of osmoregulation in the crayfish Astacus leptodactylus," Journal of Experimental Biology, vol. 206, no. 6, pp. 979-988, 2003.

[36] J. S. Chung, H. Dircksen, and S. G. Webster, "A remarkable, precisely timed release of hyperglycemic hormone from endocrine cells in the gut is associated with ecdysis in the crab Carcinus maenas," Proceedings of the National Academy of Sciences of the United States of America, vol. 96, no. 23, pp. 13103-13107, 1999.

[37] L. D. Rhodes and J. van Rebecca, "Isolation of the cDNA and characterization of mRNA expression of ribosomal protein S19 from the soft-shell clam, Mya arenaria," Gene, vol. 197, no. 1-2, pp. 295-304, 1997.

[38] Z. P. Zhang, Y. L. Wang, Y. H. Jiang, P. Lin, X. W. Jia, and Z. H. Zou, "Ribosomal protein L24 is differentially expressed in ovary and testis of the marine shrimp Marsupenaeus japonicus," Comparative Biochemistry and Physiology B, vol. 147, no. 3, pp. 466-474, 2007.

[39] G. Thomas, "An encore for ribosome biogenesis in the control of cell proliferation," Nature Cell Biology, vol. 2, no. 5, pp. E71-E72, 2000.

[40] M. Lee and T. Schedl, "RNA-binding proteins," WormBook, pp. $1-13,2006$.

[41] A. Zhou, A. C. Ou, A. Cho, E. J. Benz Jr., and S. C. Huang, "Novel splicing factor RBM25 modulates Bcl-x Pre-mRNA 5' splice site selection," Molecular and Cellular Biology, vol. 28, no. 19, pp. 5924-5936, 2008.

[42] J. L. Qi, S. H. Su, M. E. McGuffin, and W. Mattox, "Concentration dependent selection of targets by an SR splicing regulator results in tissue-specific RNA processing," Nucleic Acids Research, vol. 34, no. 21, pp. 6256-6263, 2006.

[43] Y. Xie, F. Li, B. Wang et al., "Screening of genes related to ovary development in Chinese shrimp Fenneropenaeus chinensis by 
suppression subtractive hybridization," Comparative Biochemistry and Physiology D, vol. 5, no. 2, pp. 98-104, 2010.

[44] F. H. Li, Studies on key aspects of sexual differentiation and gonad development in prawns [Ph.D. thesis], 1999.

[45] K. Nakamura, N. Matsuzaki, and K. I. Yonekura, "Organogenesis of genital organs and androgenic gland in the kuruma prawn," Nippon Suisan Gakkaishi, vol. 58, no. 12, pp. 2261-2267, 1992.

[46] A. Sagi, Z. Ra'anan, D. Cohen, and Y. Wax, "Production of Macrobrachium rosenbergii in monosex populations: yield characteristics under intensive monoculture conditions in cages," Aquaculture, vol. 51, no. 3-4, pp. 265-275, 1986. 

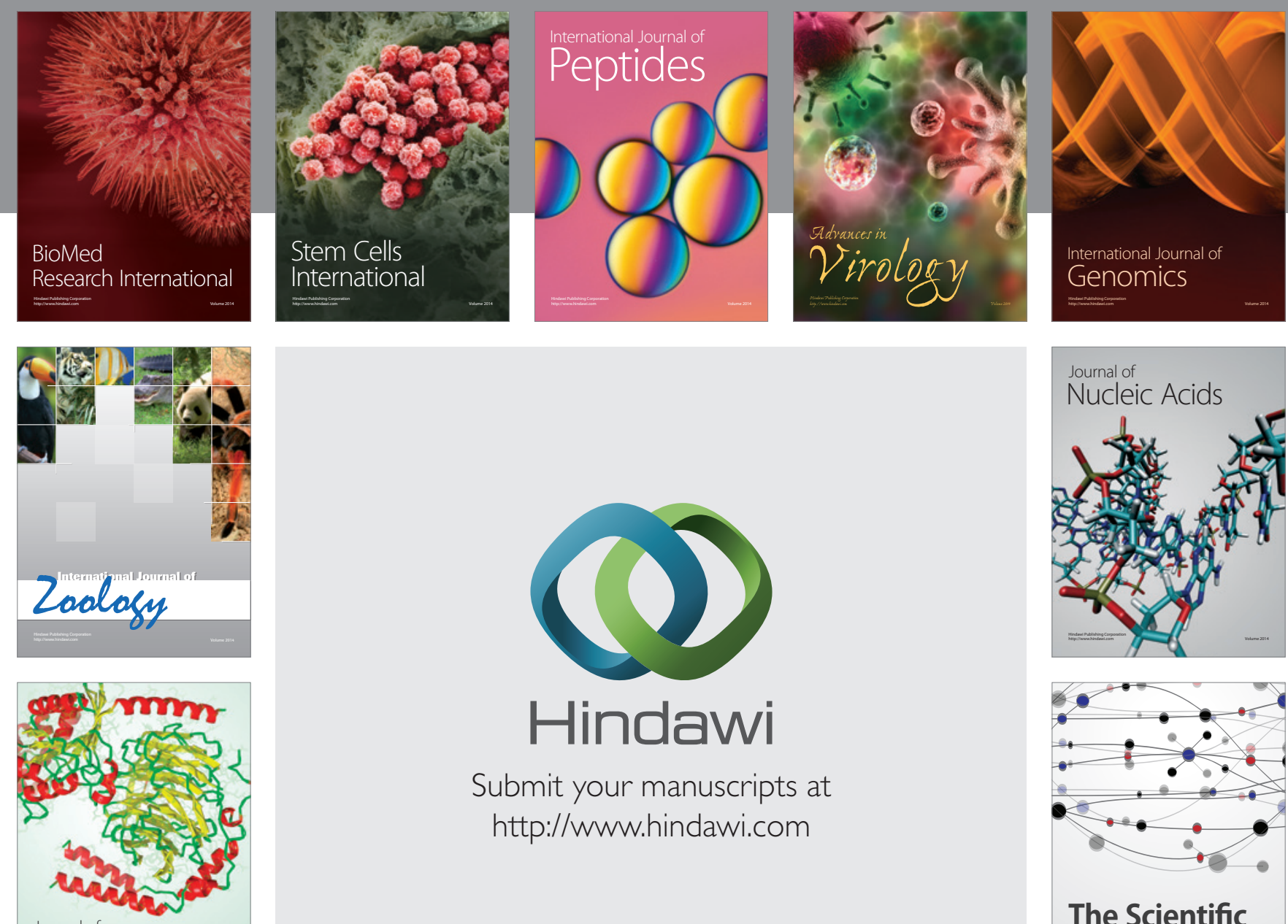

Submit your manuscripts at

http://www.hindawi.com

Journal of
Signal Transduction
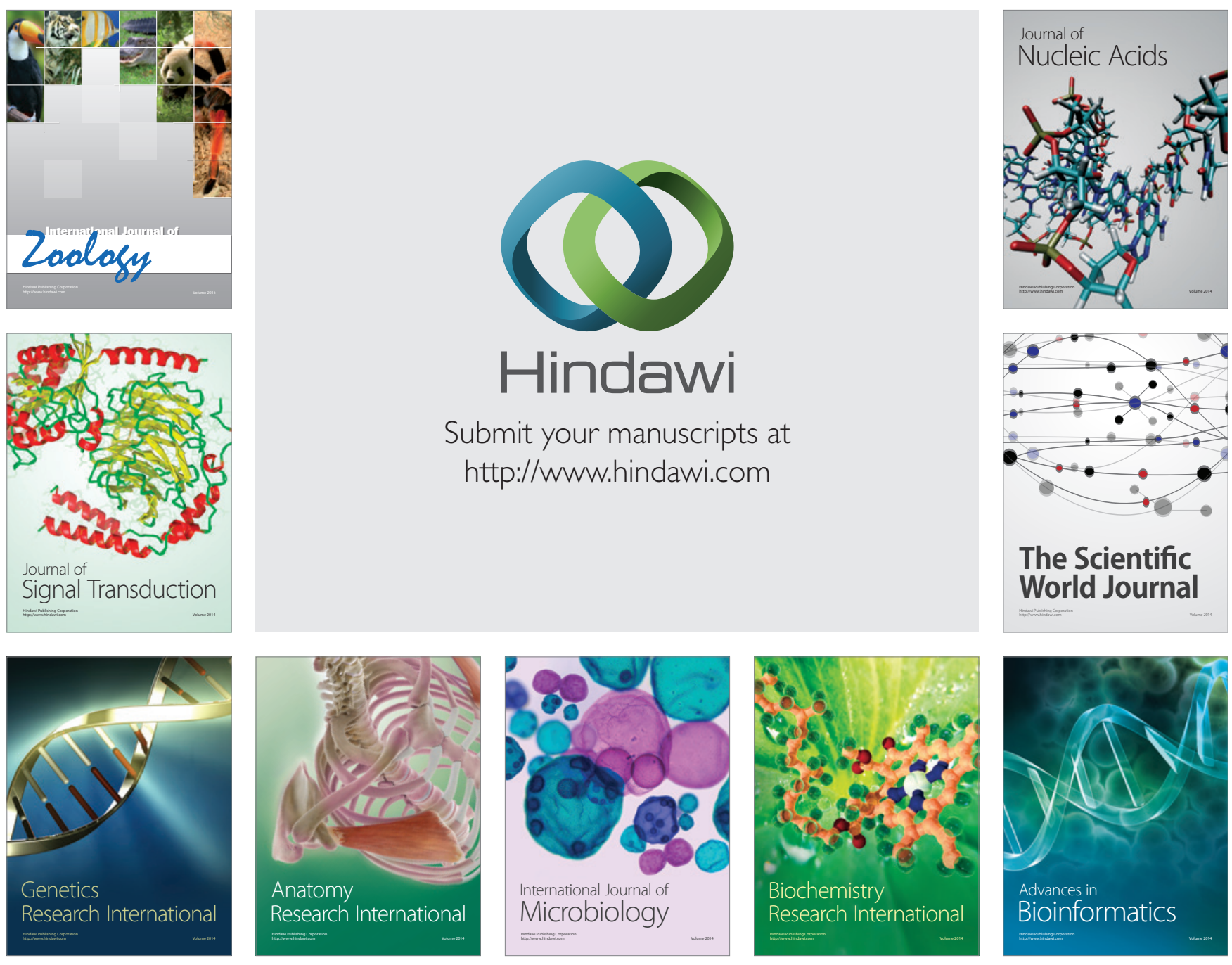

The Scientific World Journal
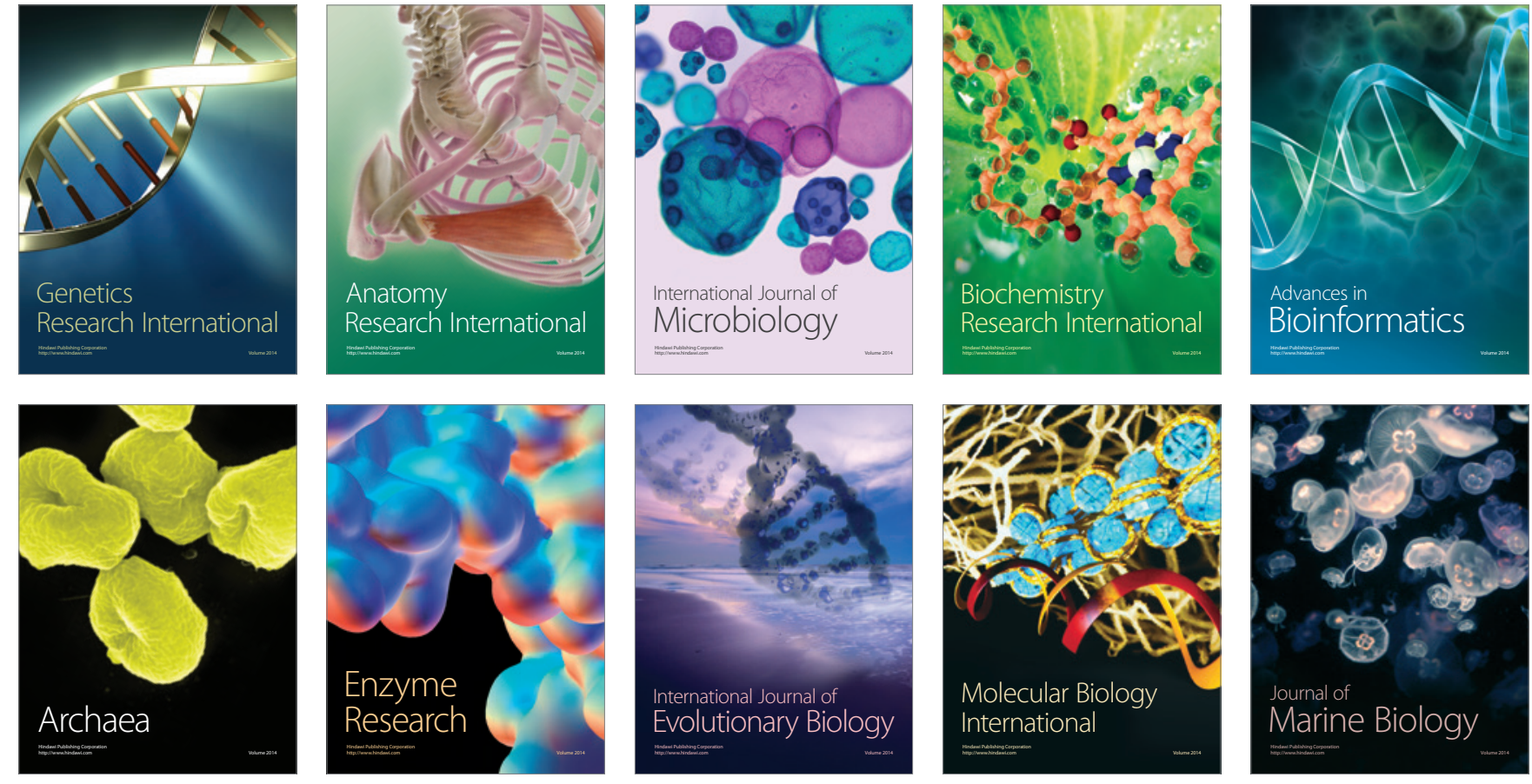